\title{
Kompetensi Profesional dan Kinerja Guru di Sekolah Avicenna Jagakarsa
}

\author{
Aep Saifullah ${ }^{\mathrm{a}, 1}$ * \\ aProgram Studi Pendidikan Pancasila dan Kewarganegaraan, \\ Fakultas Keguruan dan Ilmu Pendidikan, Universitas Pamulang \\ ${ }^{1}$ aepsaifullah11@gmail.com \\ *korespondensi penulis
}

Naskah diterima: 04-07-19, direvisi: 25-08-19, disetujui: 30-09-19

DOI: http://dx.doi.org/10.32493/jpkn.v6i2.y2019.p87-94

\begin{abstract}
Abstrak
Pendidikan merupakan bagian dari pengembangan manusia seutuhnya, kompetensi profesional dan kinerja guru sangat menentukan kualitas pendidikan. Tujuan penelitian ini adalah untuk mengetahui pengaruh kompetensi profesional terhadap kinerja guru di sekolah Avicenna. Metode penelitian yang digunakan berupa survei dengan pendekatan penelitian kuantitatif dan dibantu dengan analisis deskriptif. Populasi penelitian berjumlah 70 orang guru dengan sampel $30 \%$ (21 orang guru). Teknik analisis data dilakukan dengan program Statistical Product and Service Solution (SPSS) dan program microsoft excel. Hasil penelitian menunjukkan bahwa tingkat kompetensi profesional guru di Sekolah Avicenna dalam kategori cukup, tingkat kinerja guru di Sekolah Avicenna dalam kategori baik, dan kompetensi profesional yang diukur oleh kinerja guru memiliki pengaruh yang positif dan tidak signifikan terhadap kinerja guru.
\end{abstract}

Kata-kata kunci: kompetensi profesional; kinerja guru; pengembangan sumber daya manusia

\section{Abstract}

Education is part of complete human development, professional competence and teacher performance largely determine the quality of education. The purpose of this study was to determine the effect of professional competence on teacher performance in Avicenna schools. The research method used was a survey with a quantitative research approach and assisted with descriptive analysis. The study population numbered 70 teachers with a sample of 30\% (21 teachers). Data analysis techniques were performed using the Statistical Product and Service Solution (SPSS) program and the Microsoft Excel program. The results showed that the level of professional competence of teachers in the Avicenna School was in the sufficient category, the level of teacher performance in the Avicenna School was in the good category, and the professional competence measured by teacher performance had a positive and not significant effect on teacher performance.

Keywords: professional competence; teacher performance; human resource development 


\section{Pendahuluan}

Pada era globalisasi ini dunia tengah mengalami perubahan maha dahsyat, perubahan tersebut telah memasuki hampir semua lini kehidupan umat manusia, baik dalam lingkup individual maupun dalam kelompok sosial. Mobilitas sosial dan dinamika globalisasi sulit diprediksi dan diantisipasi dengan pancaindera, hal itu ditandai dengan cepatnya perkembangan arus informasi dan perdagangan bebas antar negara, sekedar meminjam istilah Kenichi Ohmae disebut sebagai "dunia tanpa batas" (Kenichi Ohmae, 1991:7). Hal ini terjadi karena disebabkan oleh revolusi teknologi berbasis tinggi (high-tech) terutama pada teknologi informasi dan komputer.

Selain itu, seiring dengan dinamika sosial dan upaya pembangunan manusia seutuhnya di era global, data dalam laporan UNDP tahun 2016 menempatkan Indonesia dalam Human Development Index (HDI) pada peringkat ke-113 dari 177 negara. Hal ini menunjukkan bahwa capaian pembangunan manusia di Indonesia masih tertinggal dengan negara-negara di Asia lainnya seperti Malaysia, Singapura, dan Jepang yang jauh lebih maju dalam pembangunan manusia khususnya dibidang sosial dan ekonomi.

Menyadari fenomena tersebut serta untuk mewujudkan masyarakat yang kuat dan kompetitif, maka dibutuhkan upaya dan tindakan yang bersifat praktis yang menggambarkan visi pengembangan kualitas sumber daya manusia bagi masa depan bangsa Indonesia. Salah satu pilar sosial yang cukup efektif dan efesien dalam menghadapi masalah itu adalah pelaksanaan pendidikan yang baik

Dalam implementasinya, pendidikan yang baik dan efektif bukanlah pendidikan yang hanya membangun aspek material saja tetapi juga pada aspek pengembangan sumber daya manusia dalam hal ini guru. $\mathrm{Hal}$ itu senada dengan pernyataan $\mathrm{Ki}$ Supriyoko dalam tulisannya, Revitalisasi Pendidikan Nasional mengatakan bahwa kunci revitalisasi pendidikan ada pada guru. Beliau mencontohkan dulu Ki Hadjar Dewantara dengan Tamansiswanya pernah mengajar di ruang dengan atap bocor, dinding miring, meja belajar seadanya, tetapi karena guru (pamong)nya baik, hasil pendidikannya pun baik. Banyak murid Ki Hadjar dan lulusan Tamansiswa menjadi "orang" (Kompas, 2007: 6).

Terkait dengan hal itu, lebih tegas lagi dalam Permendiknas No.12,13,16,18 Tahun 2007 secara rinci dijelaskan bahwa pendidik harus memiliki kualifikasi akademik dan kompetensi sebagai agen pembelajaran, sehat jasmani dan rohani, serta memiliki kemampuan untuk mewujudkan tujuan pendidikan nasional. Selain itu pendidik dan tenaga kependidikan diharuskan memiliki keahlian khusus yang diakui dan diperlukan dapat disetarakan dengan kualifikasi akademik melalui uji kelayakan atau kesetaraan.

Dalam proses pendidikan termasuk di Sekolah Avicenna, guru merupakan salah satu komponen penting. Oleh karena itu guru harus memiliki kualifikasi pendidikan yang sesuai dengan standar nasional dan kompetensi. Salah satu dimensi kompetensi yang penting dalam 
proses pendidikan adalah kompetensi profesional. Aktualisasi dari kompetensi profesional guru dalam proses kegiatan belajar-mengajar adalah terwujudnya kinerja yang produktif, pribadi yang kreatif, profesional, berwibawa dan menyenangkan, sehingga mampu menciptakan iklim pembelajaran yang kondusif, menantang, menyenangkan dan penuh arti bagi peserta didik.

Bertolak dari uraian di atas, maka jelas bahwa studi tentang pengaruh kompetensi profesional terhadap kinerja guru perlu dilakukan untuk memberikan sumbangan dan masukan yang relevan dengan variabel yang akan diteliti. Adapun rumusan masalah berdasarkan latar belakang masalah di atas adalah sebagai berikut: 1) Apakah terdapat pengaruh antara kompetensi profesional terhadap kinerja guru Sekolah Avicenna?; dan 2) Seberapa besar pengaruh kompetensi profesional terhadap kinerja guru Sekolah Avicenna?

Tujuan penelitian terhadap masalah tersebut sebagai berikut: 1) Untuk mengetahui pengaruh kompetensi profesional terhadap kinerja guru Sekolah Avicenna; dan 2) Untuk tingkat kompetensi profesional terhadap kinerja guru Sekolah Avicenna. Sedangkan manfaat penelitain ini yaitu dapat dijadikan sebagai tambahan bahan kajian dalam pengembangan pengetahuan mengenai pengembangan kompetensi dan kinerja dalam pembelajaran. Hasil penelitian ini diharapkan dapat berguna dan dijadikan sebagai bahan studi lanjutan yang relevan dan bahan kajian kearah pengembangan guru sesuai dengan kebutuhan dan kontekstualitas.
Hasil penelitian ini diharapkan dapat dijadikan sebagai penguatan sumber daftar pustaka, wawasan, bahan referensi dan bahan pertimbangan pemikiran bagi yang memerlukan khususnya yang ingin mengadakan penelitian lanjutan khusus pada pengembangan kompetensi dan kinerja guru. Dari hasil penelitian ini dapat dipergunakan sebagai salah satu bahan informasi dan masukan kepada pihak pengambil keputusan dalam menyelenggarakan Sekolah Avicenna yaitu; (a) Para kepala sekolah tiap unit; (b) Yayasan; (c) Direktur Pembinaan Sekolah Menengah Atas Direktorat Jenderal Manajemen Pendidikan Dasar dan Menengah Kementerian Pendidikan dan Kebudayaan.

\section{Metode}

Jenis penelitian ini menggunakan survei dengan pendekatan penelitian kuantitatif dan dibantu dengan analisis deskriptif. Penelitian yang dimaksud adalah bersifat menjelaskan hubungan kausal dan pengujian hipotesis. Seperti dikemukakan Masri Singarimbun penelitian survei dapat digunakan untuk maksud (1) penjajagan (eksploratif), (2) deskriptif, (3) penjelasan, (4) evaluasi, (5) prediksi, (6) penelitian operasional dan (7) pengembangan indikator-indikator sosial (Masri Singarimbun dan Effendi, 2003:21).

Tempat penelitian ini di Sekolah Avicenna yang alamat di Jl. Moch Kahfi Jagakarsa, Waktu dari Bulan Januari Maret 2019. Populasi dalam penelitian ini adalah seluruh guru Sekolah Avicenna yang melakukan tugas mengajar pada tahun pelajaran 2018/2019. Populasinya 
berjumlah 70 orang yang terdiri dari 54 guru tetap, 2 guru tidak tetap dan 14 orang guru honorer dari tiap unit.

Sampel dalam penelitian ini diambil secara acak (random sampling), dengan memperhatikan proporsi (imbangan) pada tiap unit, hal ini dilakukan agar sampel yang diambil dapat mewakili (representatif). Besarnya sampel yang diambil sebanyak $30 \%$ dari 70 orang yakni berjumlah 21 orang, dengan proporsi $30 \quad \%$ untuk tiap unit. Pengumpulan data dalam penelitian ini menggunakan dua teknik utama, yaitu studi dokumentasi (meliputi buku catatan kinerja guru, absensi dan lainnya) dan teknik angket.

Teknik analisis dan pengolahan data dilakukan dengan bantuan software computer, yaitu program SPSS (Statistical Product and Service Solution) dan program microsoft excel. Langkah-langkah pengolahan data dalam penelitian ini meliputi : (1) menyeleksi data agar dapat diolah lebih lanjut, (2) menentukan bobot nilai untuk setiap item variable dengan menggunkan skala penilaian yang telah ditentukan, kemudian menentukan skornya, (3) menganalisis secara deskriptif, untuk mengetahui kecenderungan data (4) melakukan uji korelasi dan regresi.

\section{Hasil dan Pembahasan}

Hasil yang dapat diperoleh dari analisis statistik secara deskriptif menunjukkan bahwa tingkat kompetensi profesional guru di Sekolah Avicenna adalah 14 orang guru $(66,67 \%)$ dari skor ideal berada pada kategori cukup, sedangkan sebanyak 6 orang guru $(28,57$
\%) dari skor ideal berada pada kategori baik dan sisanya sebanyak 1 orang $(4,76 \%)$ dari skor ideal berada pada kategori kurang. Data itu tampak pada tabel 1 yang menunjukkan nilai rata-rata keseluruhan skor 129 dari skor ideal 150.

Dengan demikian dapat disimpulkan bahwa sebagian besar guru di Sekolah Avicenna tingkat kompetensi profesionalnya masih dalam level sedang. Menurut penulis banyak faktor yang mempengaruhi terjadinya kondisi tersebut diantaranya belum meratanya kualifikasi akademik guru yang sesuai dengan standar nasional, kendala kultural, gaya kepemimpinan kepala sekolah, aspek psikologis guru dan iklim sekolah yang kurang kondusif.

Tingkat kualitas kinerja guru sebagaimana pada tabel 1, secara keseluruhan menunjukkan bahwa sebanyak 4 orang guru (19\%) dari skor ideal pada kategori sangat baik, sebanyak 9 orang guru $(43 \%)$ dari skor ideal pada kategori baik, sebanyak 5 orang guru $(23,81 \%)$ dari skor ideal pada kategori cukup, dan 3 orang guru (14,29\%) pada kategori kurang.

Data di atas membuktikan bahwa kualitas kinerja guru di Sekolah Avicenna kategori baik. Hal itu terlihat dari performa kinerja guru dalam melakukan kegiatan pembelajaran dan pelayanan pada peserta didik. Sebagian guru yang sudah melaksanakan kinerja dengan baik dipengaruhi oleh beberapa variabel diantaranya tingkat kualifikasi pendidikan dan dorongan berprestasi dari guru dan iklim yang kondusif.

Temuan itu diperkuat dengan hasil penelitian yang dilakukan Wuviani yang 
menyatakan bahwa terdapat pengaruh signifikan antara kualifikasi dan kinerja guru. Besarnya pengaruh yang diperoleh adalah 0,373 atau 37,30 \%. Data tersebut membuktikan bahwa upaya perbaikan dalam pengembangan kompetensi profesional guru adalah sebagai agenda yang perlu menjadi prioritas utama.

Temuan penelitian menunjukkan bahwa terdapat korelasi positif (korelasi yang berjalan searah) antara kompetensi profesional (X) terhadap kinerja guru (Y). Adapun besarnya korelasi kompetensi profesional $(\mathrm{X})$ terhadap kinerja guru $(\mathrm{Y})$ yang dihitung dengan koefisien korelasi adalah $r_{x y}=0,337$. Hal ini menunjukkan korelasi antara kompetensi profesional (X) terhadap kinerja guru termasuk lemah $(0,20-0,40)$.

Korelasi tersebut memiliki arti bahwa tinggi rendahnya kinerja guru di Sekolah Avicenna ada hubungannya/dipengaruhi oleh tinggi-rendahnya kompetensi profesional, sekalipun korelasi positif itu hanya cakupan saja.

Terkait dengan hasil itu, mengindikasikan bahwa pemberdayaan dan pengembangan kualitas guru dalam proses pendidikan adalah sebagai suatu keniscayaan, karena eksistensi guru dalam proses pendidikan merupakan sebagai ujung tombak untuk keberhasilan pendidikan. Sebagaimana dalam pepatah arab dikatakan : "Al-tariqah ahammu min almaddah, al-mudarris ahammu min al-tariqah, wa ruh al-mudarrs ahammu min mudarris" . Artinya : metode itu lebih penting daripada materi, guru lebih penting daripada metode, dan jiwa guru lebih penting dari pada guru itu sendiri (Abdullah Syukri Zarkasyi, 2005:133).
Secara kontekstual, pepatah di atas mengandung makna bahwa sebuah kurikulum dan metode, betapapun hebatnya dirancang, tidak menjamin berhasilnya suatu proses pendidikan dan pengajaran, karena dalam proses itu tidak ada peran profesional dari guru.

Temuan penelitian lain, menunjukkan bahwa kompetensi profesional yang diukur oleh kinerja guru memiliki pengaruh yang positif dan tidak signifikan terhadap tinggi rendahnya kinerja guru dengan nilai probabilitas 0,05 $<0,135$. Artinya tinggi rendahnya kinerja guru dijelaskan oleh kompetensi profesional guru. Derajat pengaruh kompetensi profesional yang secara langsung berpengaruh terhadap kinerja guru berdasarkan hitungan koefisien determinasi adalah $(0,337)^{2}=11,35 \%$.

Oleh karena itu, untuk mengoptimalkan kinerja guru harus diupayakan peningkatan kompetensi profesional, diantara upaya itu adalah memberikan peluang bagi guru untuk melanjutkan pendidikan baik formal maupun non formal. Hal ini sesuai dengan tuntutan dari Undang-Undang Republik Indonesia No.14 tahun 2005 tentang Guru dan Dosen pasal 45 mengatakan " Guru wajib memiliki kualifikasi akademik (minimal S1), kompetensi, sertifikasi pendidik, sehat jasmani dan rohan, dan memenuhi kualifikasi lain yang dipersyaratkan satuan pendidikan sekolah tempat bertugas serta memiliki kemampuan untuk mewujudkan tujuan pendidikan nasional.

Oleh sebab itu, apabila ada guru yang belum memenuhi standar kualifikasi pendidikan $\mathrm{S} 1$ segera dipacu dan 
ditingkatkan kualifikasi pendidikannya agar sesuai dengan standar nasional.

Upaya lain dalam pengembangan guru adalah melalui kegiatan workshop, seminar, pelatihan dan pembinaan secara berkala yang dilakukan sekolah maupun institusi lain. Dalam praksisnya kegiatan tersebut dirancang berdasarkan pada kebutuhan guru dan berorientasi pada pengembangan sekolah. Selain itu, tematema yang dapat diangkat dalam kegiatan itu dapat berbentuk masalah-masalah seperti kepribadian, pendidikan, teknologi, budaya dan karakter.

Terkait dengan pengembangan kompetensi profesional di Sekolah Avicenna masalah yang terjadi saat ini adalah gap of development. Artinya dalam pengembangan kompetensi profesional guru tidak merata, ada sebagian guru yang mendapatkan kesempatan pengembangan secara luas dan ada sebagian lagi yang kurang mendapatkan kesempatan pengembangan. Pola pendistribusian seperti ini jelas menyebabkan ketimpangan dan ketidak seimbangan dalam pengembangan sumber daya manusia. Oleh karena itu, dalam jangka penjang sekolah dan yayasan perlu mengatur kembali sistem pendistribusian itu dengan berdasarkan pada efesiensi dan efektifitas.

Temuan penelitian ini, diperkuat dengan pernyataan yang dikemukakan oleh Bernadin dan Russel sebagaimana dikutip Riduwan yang menyatakan bahwa faktor-faktor yang dapat mempengaruhi kinerja guru atau dosen meliputi pengetahuan, keterampilan, kecakapan, sikap dan perilaku (Riduwan dan Engkos A K, $2008:$ h. 232) .
Dengan demikian pengembangan kompetensi profesional guru baik melalui pendidikan formal maupun non formal perlu ditingkatkan untuk kepentingan peningkatan kinerja guru dan prestasi sekolah.

Hasil penelitian ini juga memberikan makna yang substantif bahwa profesi guru adalah profesi yang mulia dan sebagai amal saleh, karena setiap tindakan yang dijalankan guru selalu bermuara pada kebaikan dan mencerdaskan anak bangsa, tanpa guru yang berkualitas maka sudah dapat dipastikan negara akan menjadi rapuh, kehilangan daya saing dan rasa percaya diri dengan bangsa lain. Maka dari itu, permasalahan kompetensi profesional perlu dipahami secara makro dan mikro.

\section{Kesimpulan}

Berdasarkan analisis dan pembahasan tersebut, dapat disimpulkan sebagai berikut: 1) Tingkat kompetensi profesional guru di Sekolah Avicenna dalam kategori cukup; 2) Tingkat kinerja guru di Sekolah Avicenna dalam kategori baik; dan 3) Kompetensi profesional (X) yang diukur oleh kinerja guru $(\mathrm{Y})$ memiliki pengaruh yang positif dan tidak signifikan terhadap kinerja guru. Dengan demikian tinggi rendahnya kinerja guru dijelaskan oleh kompetensi profesional guru. Besarnya pengaruh kompetensi profesional yang secara langsung berpengaruh terhadap kinerja guru adalah $11,35 \%$. Berdasarkan temuan penelitian ini dapat disimpulkan bahwa hipotesis penelitian yang menyatakan "kompetensi profesional berpengaruh secara tidak signifikan terhadap kinerja guru ( $\mathrm{Ha})$ " dapat diterima. 
Berdasarkan temuan penelitian, maka rekomendasi yang diajukan adalah: 1) Para guru untuk lebih meningkatkan kompetensi profesionalnya melalui mengambil program pendidikan minimal S1 (bagi yang belum), bagi yang sudah S1 dianjurkan untuk mengambil program S2, mengikuti pelatihan, seminar, workshop dan kursus-kursus agar dapat meningkatkan kompetensi profesional guru; 2) Pimpinan sekolah tiap unit, Yayasan Pendidikan Avicenna Prestasi dan Pemerintah agar mendukung dan memberi kesempatan seluas-luasnya bagi para guru untuk meneruskan pendidikan kejenjang yang lebih tinggi dan atau memberikan kesempatan untuk mengikuti pelatihan secara merata. Salah satu langkah yang cukup menarik bagi guru adalah dengan pemberian beasiswa atau bantuan studi lainnya bagi guru yang potensial; dan 3) Kepada para peneliti agar melakukan penelitian lanjutan, untuk mengeksplorasi secara lebih mendalam tentang kompetensi profesional dan kinerja guru.

\section{Referensi}

Hamzah, U. B. (2006). Orientasi Dalam Psikologi Pembelajaran. Jakarta: Bumi Aksara.

Kenichi, O. (1991). Dunia Tanpa Batas, alih Bahasa Fx.Budyanto. Jakarta : Binarupa Aksara.

Masri, S., \& Effendi. (2003). Metode Penelitian Survei. Jakarta : LP3ES.
Mondy, W., \& Noe, R.M. (1996). Human Resource Management. Texas: Prentice Hall,.Inc.

Mulyasa E. (2003). Kurikulum Berbasis Kompetensi. Bandung : Rosda Karya.

Peraturan Menteri Pendidikan Naional Republik Indonesia No.12, 13, 16, 18 Tahun 2006 tentang Standar Pendidik dan Tenaga Kependidikan.

Razali, R. (2007). Diakses 10 Desember, Reproduksi Sosial dan Pembangunan Manusia, Republika.

Riduwan, \& Engkos. A K. 2008. Analisis Jalur. Bandung : Alfabeta.

Sukandar. (2003). Pengaruh Kompetensi Profesional Guru dan Iklim Organisasi terhadap Kinerja Guru di SLTP Negeri Semarang 1 dan SLTP Negeri Bayongbong di kabupaten Garut.Tesis. Program Pascsarjana-UPI. Tidak diterbitkan.

Supriyanti, T. (2004). Upaya Pengembangan Kompetensi Profesional Guru dalam Meningkatkan Kinerja Pembelajaran Guru (Studi Korelasional antara Perseepsi terhadap upaya Pengembangan Kompetensi Profesional Kinerja Pembelajaran Guru di SMA Negeri 1 Subang). Tesis. Program Pascasarjana-UPI. Tidak diterbitkan.

Supriyoko, K. (2007). "Revitalisasi Pendidikan Nasional", Kompas.

Zarkasyi, A. S. (2005). Gontor dan Pembaharuan Pendidikan Pesantren. Jakarta: Rajagrafindo Persada. 
Jurnal Pendidikan Kewarganegaraan

Vol. 6 No. 2 September 2019
Journal of Civics and Education Studies p-ISSN 2302-0865 | e-ISSN 2621-346X

[ halaman ini sengaja dikosongkan ] 